\title{
COPYRIGHT TRANSFER AGREEMENT
}

$3 / 12 / 14$

Contributor name: James Nicholls

Contributor address: 32 Hawthorne Street, Bristol BS4 3BZ

Manuscript number: CDEP993923

Re: Manuscript entitled: What is the problem?: Evidence, politics and alcohol policy in England and Wales 2010-14

(the "Contribution")

For publication in

Drugs: Education, Preventlon and Policy

(the Journal)

Published by

Informa UK Ltd.

("Informa")

Dear Contributor(s):

Thank you for submitting your Contribution for publication. In order to expedite the editing and publishing process and enable Informa to disseminate your Contribution to the fullest extent, we need to have this Copyright Transfer Agreement signed and returned as directed in the Journal's instructions for authors as soon as possible. If the Contribution is not accepted for publication, or if the Contribution is subsequently rejected, this Agreement shall be null and void. Publication cannot proceed without a signed copy of this Agreement.

A. COPYRIGHT

1 The Contributor EITHER:

(a) assigns to Informa, during the full term of copyright and any extensions or renewals, all copyright in and to the Contribution and all rights therein, including but not limited to the right to publish, republish, transmit, sell, distribute and otherwise use the Contribution in whole or in part in electronic and print editions of Contribution in whole or in part in electronic and print editions of languages and in all media of expression now known or later languages and in all media of expression now know

(b) In the case of U.S. Government employees or NIH funded Contributions (as notified to Informa by Contributor at the end of this Agreement) the Contributor provides informa with a nonexclusive world-wide licence to publish, republish, transmit, sell, distribute and otherwise use the Contribution in whole or in part in electronic and print editions of the Joumal and in derivative works throughout the world, in all languages and in all media of expression now known or later developed and to license or permit others to do so.

2 Reproduction, posting, transmission or other distribution or use of the final Contribution in whole or in part in any medium by the Contributor as permitted by this Agreement requires a citation to the Journal and an appropriate credit to Informa as Publisher, and/or the Society if applicable, suitable in form and content as follows: (Title of Article, Author, Joumal Title and Volume/lssue, Copyright 1 [year], copyright owner as specified in the Journal). Links to the final article on Informa's website are encouraged where appropriate.

B. RETAINED RIGHTS

Notwithstanding the above, the Contributor or, if applicable, the Contributor's Employer, retains all proprietary rights other than copyright, such as patent rights, in any process, procedure or article of manufacture described in the Contribution.

\section{c. PERMITTED USES BY CONTRIBUTOR}

1. Submitted Verslon. Informa licenses back the following rights to the Contributor, without charge, in the version of the Contribution as originally submitted for publication:

2.

a. After publication of the final article, the right to self-archive on the Contributor's personal website or in the Contributor's institution's/employer's institutional repository or archive. This right extends to both intranets and the Internet. The Contributor may not update the submission version or replace it with the published update the submission version or replace it with the published Contribution. The verslon posted must contain a logend as follows: This is the pre-peer reviewed version of the following article: [Full
cite], which has been published in final form at [link to final article].

b. The right to transmit, print and share copies with colleagues.

3. Accepted Version. Reuse of the accepted and peer-reviewed (but not final) version of the Contribution shall be solely by separate agreement with Informa. Informa has agreements with certain funding agencies woveming reuse of this version. The details of those relationships and governing reuse of this version. The doults of other offerings allowing open web use can be obtained from your Informa document.
4. Final Publlshed Version. Informa hereby licenses back to the Contributor the following rights with respect to the final published version of the Contribution:

a. Copies for colleagues. The personal right of the Contributor only to send or transmit individual copies of the final published version in send or transmit individual coples of the final published version in any format to colleagues upon their specific request, provided no fee is charged, and that there is no systematic distribution of the
Contribution, e.g. posting on a list serve, website or automated delivery.

b. Reuse in other publications. The right to reuse the final Contribution or parts thereof for any publication authored or edited by the Contributor (excluding journal articles) where such reused material constitutes less than half of the total material in such publication. In such case, any modifications should be accurately publication
noted.

c. Teaching duties. The right to include the Contribution in teaching or training duties at the Contributor's institution/place of employment training duties at the Contributor's institution/place of employment including in course packs, $\theta$-reserves, presentation at professional conferences, in-house training, or distance learning. The Contribution may not be used in seminars outside of normal teaching obligations (e.g. commercial seminars). Electronic posting of the final published version in connection with teaching/training at the Contributor's institution/place of employment is permitted
subject to the implementation of reasonable access control mechanisms, such as usemame and password. Posting the final published version on the open Internet is not permitted.

d. Oral presentations. The right to make oral presentations based on the Contribution.

5. Article Abstracts, Figures. Tables. Data Sets, Artwork and Selected Text (up to 250 words).

Contributors may reuse figures, tables, data sets, artwork, and selected text up to 250 words from their Contributions as finally published, provided the following conditions are met:

a) Full and accurate credit must be given to the Contribution.

b) Modifications to the figures, tables and data must be noted. Otherwise, no changes may be made.

c) The reuse may not be made for direct commercial purposes, or for financial consideration to the Contributor.

d) Nothing herein shall permit dual publication in violation of Joumal ethical practices.

\section{CONTRIBUTIONS OWNED BY EMPLOYER}

1. If the Contribution was written by the Contributor in the course of the Contributor's employment (as a "work-made-for-hire" in the course of employment), the Contribution is owned by the company/employer which must sign this Agreement (in addition to the Contributor's signature) in the space provided below. In such case, the company/employer hereby assigns to Informa, during the full term of copyright all copyright in and to the Contribution for the full term of copyright throughout the world as specified in paragraph $A$ above.

2. In addition to the rights specified as retained in paragraph $B$ above and the rights granted back to the Contributor pursuant to paragraph $\mathrm{C}$ above, Informa hereby grants back, without charge, to such company/employer, its subsidiaries and divisions, the right to make 
CDEP 993923 What is the problem?: Evidence, politics and alcohol policy in England and ...

copies of and distribute the final published Contribution internally in print format or electronically on the Company's internal network. Copies so used may not be resold or distributed extemally. However the used companfomployer may include information and text from the Contribulion as part of an information package included with software or other products offered for sale or license or included in patent applications. Posting of the final published Contribution by the institution on a public access website may only be done with Informa's written permission, and payment of any applicable fee(s). Also, upon payment of Informa's reprint fee, the Institution may distribute print copies of the published Contribution externally.

E. GOVERNMENT CONTRACTS

In the case of a Contribution prepared under U.S. Government contract or grant, the U.S. Government may reproduce, without charge, all or or grant, the U.S. Government may reproduce, without charge, all or U.S. Govemment purposes only, if the U.S. Government contract of grant so requires. (U.S. Government, U.K. Govemment, and other government employees: see notes at end).

F. COPYRIGHT NOTICE

The Contributor and the company/employer agree that any and all copies of the final published version of the Contribution or any part thereof distributed or posted by them in print or electronic format as permitted herein will include the notice of copyright as stipulated in the Journal and a full citation to the Joumal as published by Informa.

G. CONTRIBUTOR'S REPRESENTATIONS The Contributor represents that the Contribution is the Contributor's
original work, all individuals identified as Contributors actually contributed original work, all individuals identified as Contributors actually contribute
to the Contribution, and all individuals who contributed are included.

If the Contribution was prepared jointly, the Contributor agrees to inform the co-Contributors of the terms of this Agreement and to obtain their signature to this Agreement or their written permission to sign on their behalf. The Contribution is submitted only to this Joumal and has nol been published before. (If excerpts from copyrighted works owned by third parties are included, the Contributor will obtain written permission from the copyright owners for all uses as set forth in Informa's permissions form or in the Journal's Instructions for Contributors, and show credit to the sources in the Contribution.) The Contributor also warrants that the Contribution contains no libellous or unlawful statements, does not infringe upon the rights (including without limitation the copyright, patent or trademark rights) or the privacy of others, or contain material or instructions that might cause harm or injury. The Contributor further warrants that:

(a) wherever possible and where appropriate any patient, client or participant in any research, experiment or study, who is mentioned in the Contribution has given consent for material pertaining to themselves, to be included in the Contribution and that they have acknowledged to the Contributor that they cannot be identified by the Contribution in any way; and

(b) they shall include in the Contribution appropriate warnings concerning any particular hazards that may be involved in carrying out experiments or procedures or involved in instructions, materials, or formulae described in the Contribution, and shall mention explicitly relevant safety precautions and give, if an accepted code of practice is relevant, a reference to the relevant standard or code.

The Contributor undertakes to advise the Publisher if any part of the Contribution is affected by technological, commercial or legislative developments which might make it necessary or advisable for the Article to be amended, altered or updated.

H. ASSIGNMENT

Under this Agreement the Publisher may assign its rights or obligations without the consent of the Contributor.

I. NO EMPLOYMENT

Nothing in the Agreement shall constitute or should be construed as constituting a partnership or contract of employment between the parties and the Publisher shall not be responsible for the provision of an benefits, pension, sick pay or national insurance contributions. In addition, the Contributor shall be responsible for all taxes relating to the Contributor's services under this Agreement and shall keep the Publisher indemnified against any claim against the Publisher in respect of the same.

\section{J. GOVERNING LAW}

Each Party to this Agreement irrevocably agrees that this Agreement is construed under English law and submits to the non-exclusive jurisdiction of the English courts to settle any disputes arising out of or in connection with this Agreement or its fomation.

\section{CHECK ONE BOX:}

$\square$ Contributor-owned work

Company/lnstitution-owned work (made-for-hire in the course of employment)

Company or institution (Employer-for-Hire)

Authorised signature of employer

Date:

U.S. Govemment work Note to U.S. Government Employees

A contribution prepared by a U.S federal government employee as part of the employee's official duties, or which is an official U.S Government publication is called "U.S. Government Work," and is in the public domain in the United States. In such use, the employee may cross out Paragraph A1(a) but must sign (in the Contributor's signature line) and return this Agreement. If the Contribution was not prepared as part of the employee's duties or is not an official U.S. Govemment publication, it is not a U.S. Government Work.

U.K. Government work Note to U.K. Government Employees

(Crown Copyright) The rights in a Contribution prepared by an employee of a U.K. government department, agency or other Crown body as part of his/her official duties, or which is an official government publication, belong to the Crown. U.K. government authors should submit a signed declaration form together with this Agreement. The form can be obtained via htto://umw.opsi.gov.uk/advice/crown-copvriaht/copvriaht. declaration form together with this Agreement. The form can be obtained

Other Government work Note to Non-U.S., Non U.K. Government Employees

If your status as a government employee legally prevents you from signing this Agreement please contact the editorial office.

\section{NiH Grantees Note to NIH Grantees}

(Also check another box) Pursuant to NIH mandate, Authors may post the accepted version of Contributions authorised by NIH grant-holders to PubMed Central upon acceptance. This accepted version will be made publicly available 12 months after publication. For further information see htto:lloublicaccess. nih.gov/address cepvioht.htm

\section{ALL CLASSES OF CONTRIBUTOR MUST SIGN HERE:} Contributor's signature

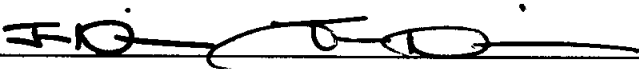
Date:

Type or print name and title Dr James Nicholls 